\title{
Geo Dynamics, Salinity Gradient, and Vegetation Interdependence in Chilika Lagoon, a Tropical Wetland in Eastern India
}

\author{
Siba Prasad Mishra ${ }^{1}$, Sujit Kumar Mishra ${ }^{2}$, Kalptaru Das ${ }^{1}$ \\ ${ }^{1}$ Dept. of Civil Engineering, Centurion University of Technology and Management, Bhubaneswar, Odisha, \\ India \\ ${ }^{2}$ Wetland Research and Training Center, Chilika Development Authority, Balugaon, Odisha, India
}

\begin{abstract}
Chilika a shallow brackish lagoon, India, is shrinking for sediment surplus budget. South Mahanadi deltaic branches i.e. Daya and Bhargavi terminate at the southwest swamps of the Lagoon. The annual average salinity of the lake was depleted from $22.31 \mathrm{ppt}$ (1957-58) to $8.5 \mathrm{ppt}$. (1999-2000) as the mixing process of saline and fresh water was influenced from 1995. Trepidation of conversion of Chilika to a atrophied fresh water lake due to blooming population and their hydrologic interventions like Kolleru lake in (India), Aral Lake (Uzbekistan) was apprehended by 1950's and was alarming by 1999 when the shallow inlet(s) shifted extreme north. The shallow mud flats of lean salinity were reclaimed further for agriculture. The ecology and biodiversity degraded with substantial pecuniary loss to the lagoon dependents. Anthropogenic interventions like, Hirakud Dam (1956), dredging of Sipakuda Inlet (2000), Naraj barrage at delta head (2004), Gobardhanpur barrages (1998) and Gabkund cut with weir (2014) were made to the hydraulic system. The deteriorating health, perturbed biodiversity and declined ecosystem of the lagoon has forced to have a comparative study of the various morphologic changes passed over the Chilika with time. The meteorological, hydrologic, and the salinity study of the lagoon area for the period 1990 to 2016 have shown changes. Topographic study using GIS is developed by collecting data from Glovis Classic (Google) and the interpretation is done using ERDAS 9.2 software for various geomorphic features (1984 and 2017) before and after the current anthropogenic interventions and compared with previous studies.
\end{abstract}

Key words: Chilika Lagoon, Tidal inlet, Geomorphology, Mahanadi Delta

\section{INTRODUCTION}

Coastal lagoons vary decreasingly in number from equator to pole and cover about $13 \%$ of the onshore coastal areas. The sea level fluctuations play pivotal role on the young dynamic water body, which was formed during mean sea level rise (MSL) fluctuation during Holocene. The Venice Lagoon (Italy), Jubho Lagoon (Pakistan), Coorong Lagoon (Australia), Lake St. Lucia (South Africa), and Lagoa dos Patos (Brazil) and most of the lagoons are in a state of threats from climatic

Correspondence: Sujit Kumar Mishra, Wetland Research and Training Center, Chilika Development Authority, Balugaon, Odisha, India, Email: sujtmsr@gmail.com quirks, sedimentation, anthropogenic activities and salinity regime. The lagoons in India are the Chilika (Odisha), Pulikat (A.P. \& TN), Kaliveli (TN), Vembanad (Kerala). They are also victims of MSL variability, meteorological extremes, river inputs, and salinity variations.

Chilika Lake, the largest in Asia and second in the world, is a shallow lagoon sprawls along east coast of India. The brackish water body spreads over an average $1045 \mathrm{~km}^{2}$ during monsoon, $790 \mathrm{~km}^{2}$ during mid-eighties and further reduced to $760 \mathrm{~km}^{2}$ during nineties (Ghosh 2003). The pear shaped wetland has maximum and minimum depth from $4.88 \mathrm{~m}-$ 
$0.6 \mathrm{~m}$ (1858) (Pearson 1858) to $1.42 \mathrm{~m}$ to $0.42 \mathrm{~m}$ in monsoon and summer respectively (19951996) (Mishra et al 2015). The $64.3 \mathrm{~km}$ long barrier spit between the lagoon and the Bay of Bengal (BoB) is stable for its $33.3 \mathrm{~km}$ and width $3-15 \mathrm{~km}$ from south is thickly habituated. Rest $31 \mathrm{~km}$ is of width 0.15 to $1.5 \mathrm{~km}$ is narrow, dynamic and fragile with all Tidal inlet (TI) dynamics and mangroves Fig. 1(a). The lagoon comprises of three sectors northern sector (NS), central sector (CS), southern sector (SC) and with a shore parallel outer channel (OC) of varying length 30 to $32 \mathrm{~km}$. The salinity gradient and all fluvial hydrodynamics are controlled by the tidal inlets (TI) in the spit.

The Chilika has an overall area of 1570 $\mathrm{km}^{2}$ (including coast) and extends from the Rambha Hills to extreme southern corner of
South Mahanadi Delta (SMD). The lagoon lies between two deltaic promontories of the rivers Daya and the Rushikulya. The lagoon acts as a balancing reservoir for discharge of the rivers Daya and Bhargavi system which contribute 60$70 \%$ water volume of the lagoon Fig. 1(b). The basins area of SMD is $1777 \mathrm{~km}^{2}$ and the western catchment area is $2800 \mathrm{~km}^{2}$ (Mishra et al., 2013). The lagoon has a fragile marinebrackish-fresh water ecosystem.

which is maintained by salinity gradient. The major sediment transport to the lagoon area is either with the floods or by tides. The area adjacent to NS is of young alluvial landform of SMD whereas the western catchment is hilly terrains of the EGB Hills Fig 1(a) and Fig 1(b).

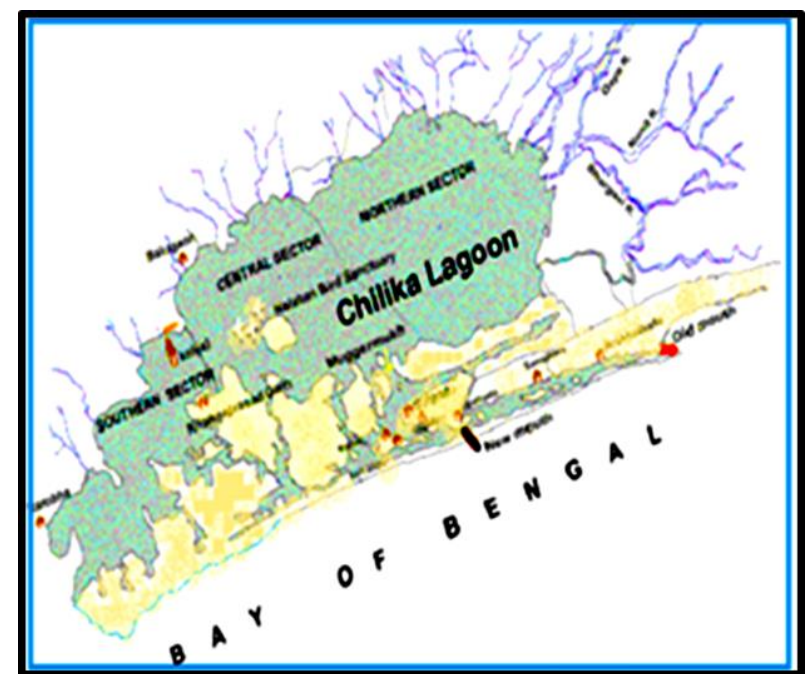

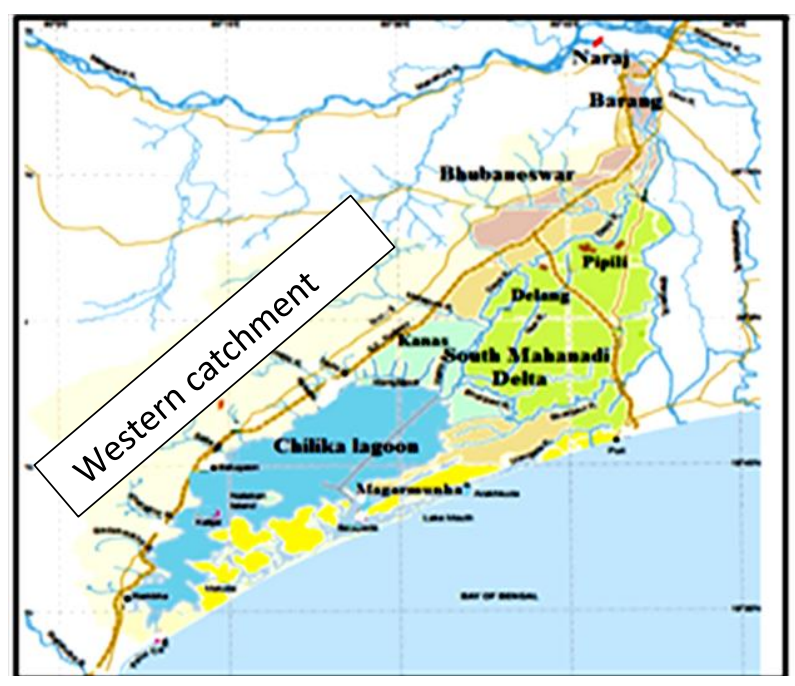

Figure 1. The Chilika and morphologic division (a) and the South Mahanadi Delta and Chilika (b)

The study area is bounded by latitudes $19^{\circ}$ $28^{\prime}$ and $19^{\circ} 54^{\prime} \mathrm{N}$. and $20^{\circ} 24^{\prime} \mathrm{N}$ lat., and $85^{\circ}$ $67^{\prime} \mathrm{E}, 85^{\circ} 35^{\prime} \mathrm{E}$ and $86.57^{\prime} \mathrm{E}$ long. The area is covered in Survey of India (TS) numbers E45B, $74 \mathrm{E} / 01,74 \mathrm{E} / 02,74,74 \mathrm{E} / 03,74 \mathrm{E} / 05,74$ E/06, $74 \mathrm{E} / 09,74 \mathrm{E} / 10 \mathrm{E} 74 / 6$ and $\mathrm{E} 74 / 16$ of scale 1:50000. Present monitoring of the area was done by GIS studies. The present research work elucidates the geodynamic transforms, barrier spit, topography, morphology, salinity gradient of the Chilika Lagoon. The interdependence of the geodynamic transforms 
and the consequential changes LU/LC within the lagoon and adjoining areas of Puri District in SMD is also studied using GIS imageries from 1975 to 2017.

In 1870, the geographical coastal length, maximum average width of the lagoon were $70.81,32.2,8.05 \mathrm{~km}$ respectively and average depth 0.9 to $1.5 \mathrm{~m}$ except some places more than $3 \mathrm{~m}$ Sterling (1846). Pearson (1858), Harrish J. C. (1860) were the investigators who prepared the first Bathymetry map of the lagoon. The first spur (human intervention) was constructed at Naraj in 1958 and furthers improved to a barrage in 2004. The flow distribution in the branches Daya and Bhargovi Rivers were $2.6 \%$ and $1.9 \%$ respectively of total flow of the trunk river Mahanadi Mahalanobish (1928). There were changes in the geomorphology, hydrology, and hydrodynamics of the lagoon and in the (SMD) with time (Das and Jena, 2008; Gupta, 2008; Mishra et al., 2012). The average length, breadth, depth of the lagoon were reduced to $64.5 \mathrm{~km}, 3-25 \mathrm{~km}$ and $0.5-2.9 \mathrm{~km}$ respectively except the dredged channel of $6.0 \mathrm{~m}$. There was prolific change in lake ecology and biodiversity after dredging of the mouth in front of Sipakuda as reported by CDA Report (2012-13) (Gupta et al., 2010; Sahu et al. 2014).

The lagoon was reported of about 3000 years old and had gone many a geospatial transformation (Venkatratnam, 1970; Mahalik, 1996; Kadekodi, 1999; Nayak et al., 2006; Lal et al. 2009; Iwasaki, 2016). CWPRS evaluated the rate of drift was 1.2 Mcum in 2000. The average annual sediment load to Chilika during 19992007 was 0.89 MMT i.e. $75 \%$ of total load (0.66 MMT) was contributed by the Mahanadi system. In 2007, the Bay deposited 0.81 MMT of sediments within the lake (Chilika Newsletter Journal of Wetlands Environmental Management Vol 7, No 1 (2019) 1 - 22 http://dx.doi.org/10.20527/jwem.v7i1.186
Volume - V - Wetlands International). The vertical gradient of the lagoon undergoing dispersal mechanism like surface water, salinity and $\mathrm{pH}$ of the lagoon is $\approx 1, \approx 2$ and $\leq 1$ (Panda et al., 2008). During 2009-10, 1400 Cumec flood was discharged to sea through all the inlets during flood and inflow from Bay of Bengal was 1110 cumec during ebb tides whereas total tidal prism during flood is 19.2 Mcum and 18.0 Mcum during ebb tides (Gopi Krishan et al., 2014). About 13 MMT of sediment enter the Chilika carried by 10667 MCum of water (Kadekodi et al., 1999) out of which $90 \%$ of silt surpasses the lake and enter direct to sea during flood (Chkrapani et. al., 2005). Sediment studies on the lake has been undertaken showing excess sedimentary balance is depleting the lake Delta Development Plan (Chandramohan, 1993; Mishra et al., 2012; Abinash, 2013). The distribution of sea grass meadows were within the central and southern west coasts of the shallow lagoon, with annual carbon sequent ion rate 10.1 to 16.8 Ton $\mathrm{CO}_{2}$ equivalent $\mathrm{ha}^{-1}$ covering an area of $85 \mathrm{~km}^{2}$ (Ganguly et al., 2017). The water of the lagoon from 2006 to 2014 was in eutrophic state and trophic state index was low during post monsoon period in 2013-14 (Jally et al., 2016).

Study of land use and land cover (LU/LC) by using GIS and satellite imageries are widely accepted at present for monitoring and management of basins/watersheds of the water bodies. (Lo Yang et al., 2002, Ye Bai et al., 2008; Singh et al., 2013; Rawat et al., 2014). Ojha et al., (2013), Singh et al 2013, Rout J 2013, Islam (2013), Rawat et al. 2014, Sahu et al., 2014 Gupta, 2014) and Goswami et al. (2017) have reported from their GIS studies of the lagoon area that vegetation, flora and fauna in the catchment (i.e. SMD and western 
catchment) have deteriorated and there is diminution of the lake area and changes in geomorphology. The greenery transform have upset of biodiversity, hydrology, limnology, and other geomorphologic features which has influenced the climatic and ecological alterations. Mahanty et al, 2016 found the residence time is 4 to 5 days in the outer channel and 132 days in the lake body. Watanbe et al., 2016; Fabiola et al. (2016) have shown through GIS imageries that tsunami-2004 has less impact on the geomorphology of Chilika Lagoon. The action of turbulent flow on the suspended sediment in a plume and found turbulent bursting occurs with a momentum sediment flux correlation Wijeratne et al 2017. High $\mathrm{NO}_{3}{ }^{-}$concentration, low $\mathrm{DO}$ value of water in Chilika (0.01 to $02 \mu$ mole/L) result in increase in chlorophyll ( $4 \mathrm{~m} \mathrm{cum}^{-1}$ ) Rajkumari et. al.,2010. Chilika Lagoon is at eutrophic (4963 Carlson TSI) state from 2013 to 2015, Jally et al 2016. Nazneen 2017 reported that the texture, influx of sediment, algal growth and the human interventions play pivotal role in variation of low organic carbon but high $\mathrm{N}, \mathrm{P}$, and silica concentration which is found in the sediment cores of the OC and NW swamps of the Chilika. Sea grass are proliferated in the west bank of the Chilika Lagoon as a mark of Blue Carbon Sequestration covering an area of $86.84 \mathrm{~km}$ in 2012. Philips J. D., 2017 reported that the geomorphic resilience in a coastal lagoon is not absolutely a property of the system but are geospatially free. The MSL rise of adjacent sea is governed by local geomorphology. The residence time of the lagoon is heterogeneous, site specific and regulated by seasonal activities and varies from a week in OC to 132 days in swamps of northern sector during a year Mohanty et al 2016. Islam Sk. M. 2016 reported that the total catchment area of the Chilika lagoon (SMD + Western) is approximately $5240 \mathrm{~km}^{2}$.

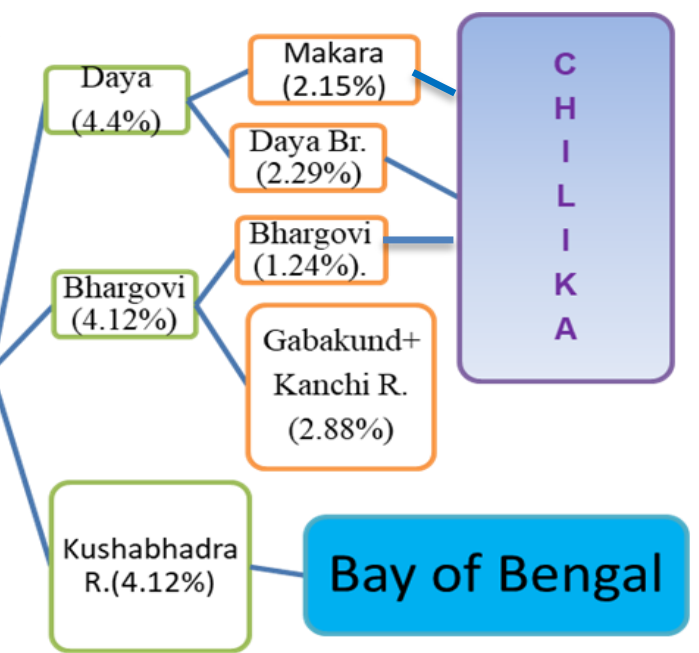

Figure 2. The fresh water inflow system from SMD to the Chilika Lake.

The lagoon had a depleted TI (at Motto) in 1999, $32 \mathrm{~km}$ from Magarmunha, was delaying the ingress/mix and thus reduces the salinity of the lagoon. Following the risk model results, Sipakuda inlet was dredged in front of
Magarmunha to augment flow exchange and to raise salinity gradient to save the eco-health of the lagoon. Hirakud dam (1956), Sipakuda TI (23 ${ }^{\text {rd }}$ Sept, 2000), Naraj barrage at head of SMD (2004), Gobardhanpur barrage (1998), 
Gabkund (submerged weir) and weir (2014), Mangala cuts to $\mathrm{BoB}$ from the river Bhargavi are the major hydrological interventions. Seasonality and anthropogenic activities have heterogeneity in coastal ecosystem Bharati et al, 2017. Hirakud dam was unable to control sedimentation of Chilika lagoon. The $940 \mathrm{~m}$ long Naraj barrage, (latitudes $20^{\circ} 24^{\prime} \mathrm{N}$ and longitudes 86.57' E) with design discharge of 29500 cumec has been effective. But a dry spell is running from 2015 to 2017 in the Mahanadi basin. But after construction of Gabakund submerged weir with a pilot channel, the summer flow is regulated in the river Bhargavi. But $55-60 \%$ of the flood of the Bhargavi drains to Bay without reaching the Chilika depriving its flushing flow. The flow scenario of Mahanadi system is draining to Chilika (Fig. 2).

\section{MATERIAL AND METHODS}

Hydrological data (1998 to 2013) for eight river gauge and discharge $(\mathrm{G} / \mathrm{D})$ stations of the inflowing rivers around the lake catchment were collected and analyzed. Hydrologic data of the inflowing major rivers to Chilika, have been taken for the period 2001, 2002, 2003 (preinterventions) and 2009, 2011 and 2013 for post interventions. The discharge data of Naraj Barrage which is the major source of flow has been collected. The Morpho-dynamic changes in the lagoon have been gathered from field visits, old available literatures, books and web sites.

The synoptic view in GIS is designed to capture, preserve, handle, study and manage the

4. Atmospheric correction for any meteorological interventions like noises and clouds existing geographic data. The Satellite data and GIS were used to analyze the dynamics of evolution and morphologic changes and study the Land use and land Cover of the Chilika. Images from Landsat 2 Multispectral Scanner System (MSS), Landsat 5 Thematic Mapper (TM), and Landsat 8 Operational Land Imager (OLI) were available to extract the land cover maps. A cross-tabulation detection method in the geographic information system (GIS) module was used to detect land cover changes during the 1st period (1976-1998) and 2nd period (1998-2014). GIS technology was developed using the Multi Spectral Scanner (MSS), Thematic Mapper Sensors (TMS) and Enhanced Thematic Mapper Sensor Plus (ETMS+) in satellites LANDSAT 5 or 7 (or 8) and RESOURCESAT to get better resolution results. Google Earth uses high resolution images like digital Globe quick bird which is 65 $\mathrm{cm}$ panchromatic at nadir that operates few hundred km above the Earth's surface to give those high resolution images (https://www.gearthblog.com/blog/archives/201 4/04/google-earth-imagery.html). The steps involved in the process are:

1. Collection of satellite data from Land Sat series from Glovis classic (Landsat Series Thematic mapper -5)

2. Interpretation of the data using ERDAS 9.2 software to create a layer stack (Digital Image Processing)

3. Focal analysis was done to check the disc tripping

5. Data preparation was done and a subset image was prepared 
6. Classification was done to have a thematic map (Land Use and Land cover map)

7. Accuracy was checked (should be more than $85 \%$ )

8. Preparation of Land use /Land cover (LU/LC) map

Satellite imageries were collected from Google Earth for the thematic maps of Chilika from 1984 to 2017 and processing was done. Transgressed geomorphologic changes of the coast were studied before and after anthropogenic interventions.

Present study covers the vicissitudes in LU/LC in the lacustrine brackish water body and adjoining areas in SMD in Puri district for past 42 years. The Landsat \&IRSP6 LISS III satellite imageries of 1975, and 1995, 2012, 2013 of Ojha et al. (2014), and Rout J. (2013) were considered in the study. The GIS technique was used to find the land use and land cover map of Chilika and SMD area for the year 1985 and 2017 with an accuracy of $86 \%$.

Chilika lagoon has a catchments area of $4577 \mathrm{~km}^{2}$ (Mahanadi catchment and Western catchment) consisting of 52 rivers, rivulets and drainage channels. They contribute fresh water into the lagoon only during the monsoon and post-monsoon season. For the convenience of the study, only 13 major rivers and rivulets contributing $90 \%$ of the fresh water were taken for monitoring the monthly discharge for the period 2001 to 2003 (Fig. 3).

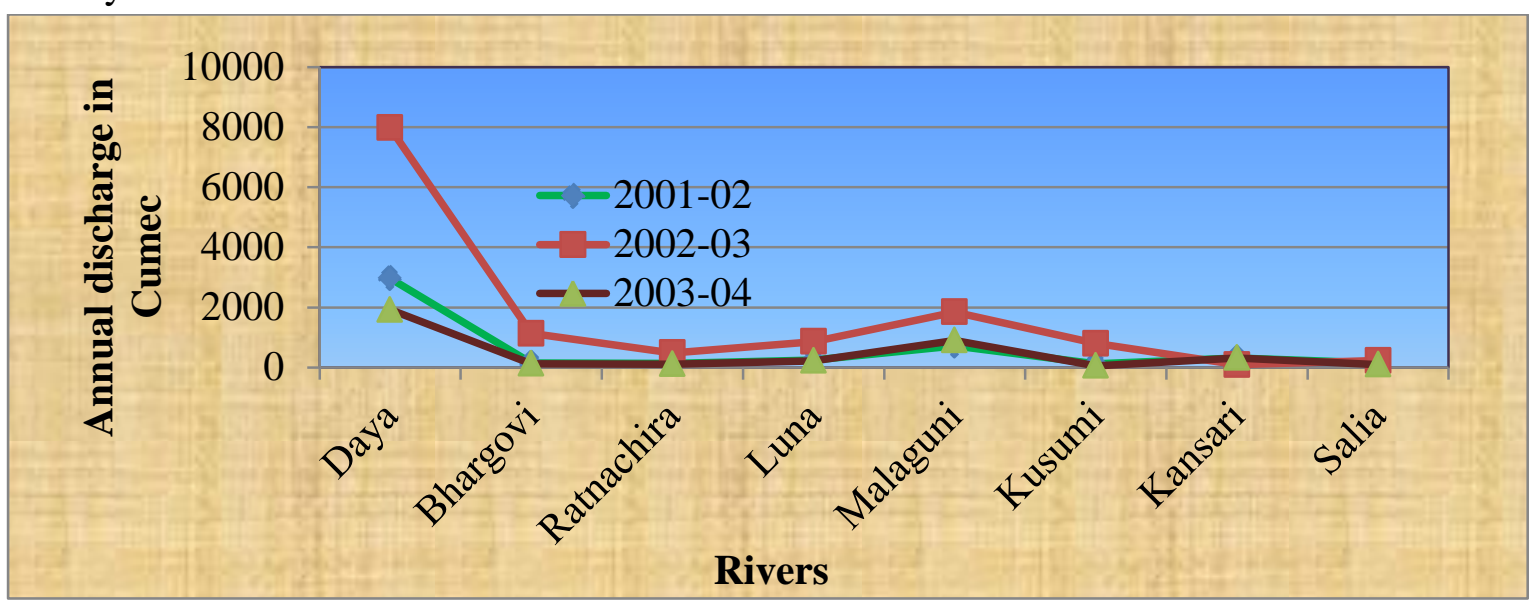

Figure 3: Annual flow to the Chilika from during SW Monsoon in the year 2001, 2002, 2003

Figure 4 represent the pre-barrage and 2009, 2011, 2013 Figure 4 the post barrage where flow to Chilika through the main rivers are recorded. From the graphs, it shows the river Daya carries maximum flow to Chilika and Sep and Oct are the months of high quantity of inflow to the lake. In 2009, there was excess rainfall in the basin which discharged excess runoff to the lagoon. The flow has drastically reduced owing to dry spell in Mahanadi basin 2014 to 2017 (Fig. 4). 


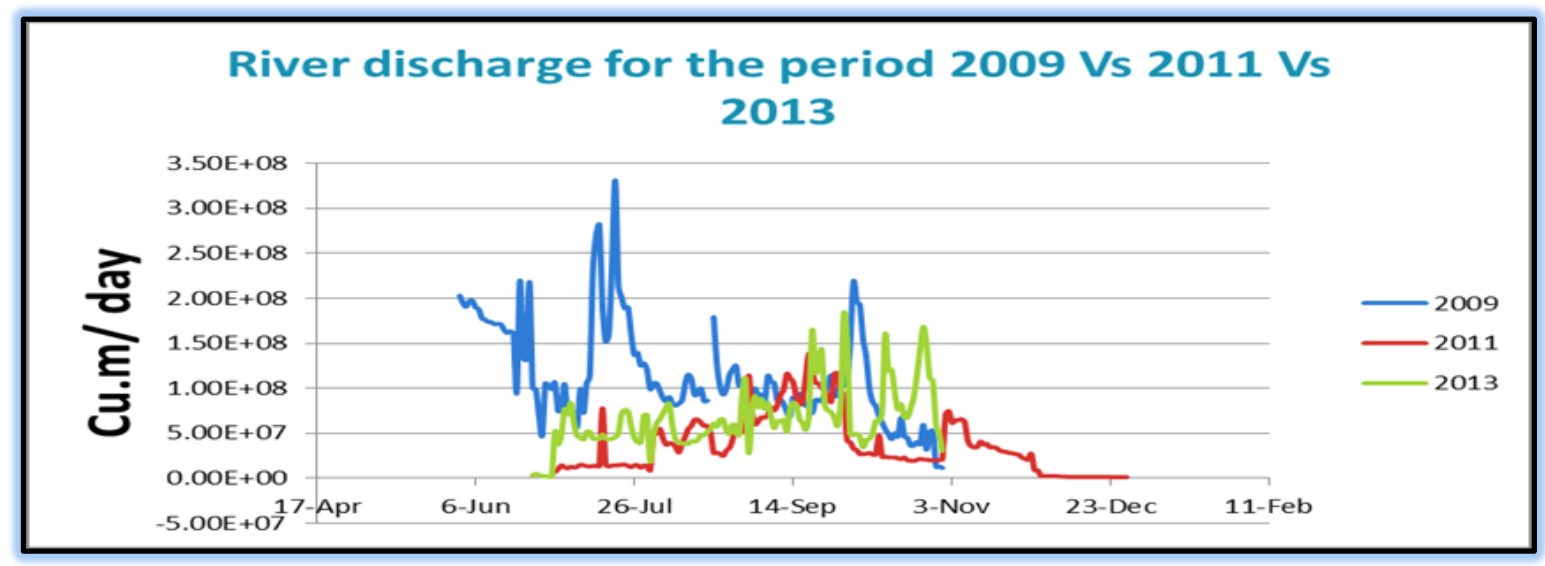

Figure 4. Annual fresh water flow to the Chilika during SW Monsoon from catchment year 2009, 2011, 2013

\section{Tidal Inlets}

Chilika has continuously north moving TI's, varying in number and dimension which maintain the marine-brackish-fresh water ecosystem. The post intervention geomorphologic changes in the in the Tidal inlets (TI) are the closure of old Motto TI's 2004, subsequent merger and closing of Sipakuda , Mirjapur and Gabakunda TI by 2014, further opening/migration of the five new natural tidal inlets Dahlbali (Baidhar) (2012), Chadachadi (Dhaulakuan) (2014),), Dhala Kuan near Nanganasi (2016) and Gaikona (2017) till date. The high tides from 18th to $21^{\text {st }}$ Oct and from $15^{\text {th }}$ Nov $17^{\text {th }}$ November 2017 have eroded the guard walls in the OC near Sanapatna (Fig. $5)$.

\section{Tidal prism}

Paul et al. (2014) estimated the tidal prism volume during pre-human interventions were $93,312,000 \mathrm{~m}^{3}, 62,208,000 \mathrm{~m} 3$ and $38,880,000$ $\mathrm{m}^{3}$ in the year 1972, 1990 and on 12. 09. 2000 during pre-interventions respectively. The vertical mix was improved during postintervention and multi-TI period. It was $62,208,000 \mathrm{~m}^{3}, 93,312,000 \mathrm{~m}^{3}$ and 202176,000 $\mathrm{m}^{3}$ in the year 2004, 2009, and 2013, respectively. The flow dynamics of the Chilika is governed by the flood deltas in OC not by the insignificant ebb deltas like the river estuaries of the Mahanadi System. The number and dimensions of flood deltas in OC increase during the drought period in the basin. 

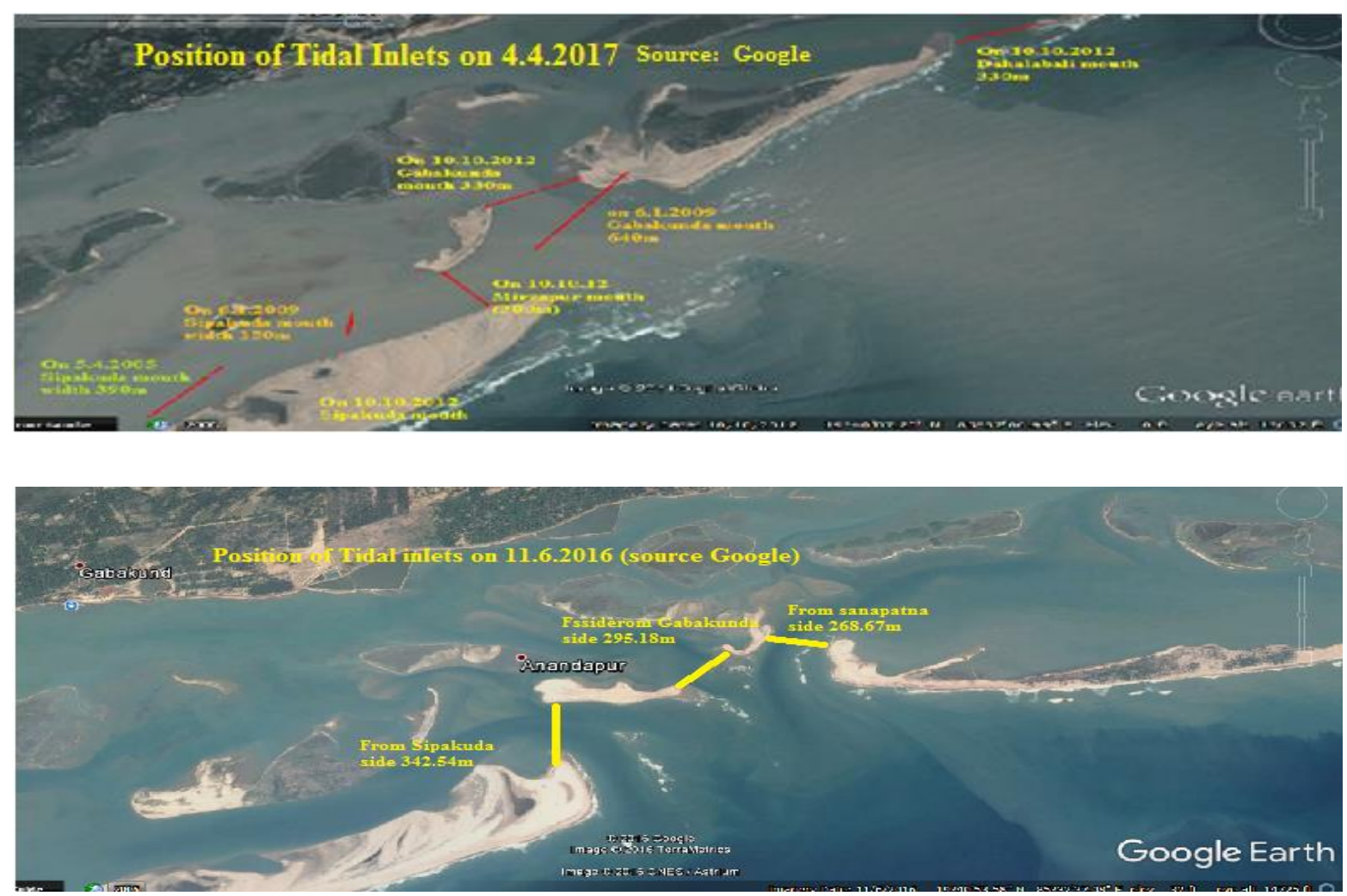

Figure 5. Spit dynamic TI's and flood deltas (a. Dt. 4. 4. 2013 and on Dt. 11. 6. 2016)

\section{Long shore drift}

The semi-stable coast of the Lake is microtidal with mean tidal range of $1.29 \mathrm{~m} \&$ semidiurnal tidal cycle 12.42 hours. The tidal flux is increasing from $0.36 \mathrm{~m}$ to $0.80 \mathrm{~m}$ (observation 1999-2006) along Chilika curved coast (CDA Report 2012) ${ }^{[4]}$. Waves of $3 \mathrm{~m}$ high (maximum) strike coast obliquely ( $\mathrm{S}-$ to $\mathrm{SW}$ direction). The long shore sediment drift near shore is northerly of about 6000 Cumec with maximum wave height of $3.8 \mathrm{~m}$ (post monsoon) to 19000 Cumec (pre-monsoon) with spring tidal amplitude $2.39 \mathrm{~m}$ and neap tidal amplitude 0.85 $\mathrm{m}$. The surplus sediment budget of longshorsediment and inland sediment from floods is the major causes for sedimentation of the lagoon. Inland floods contribute less to sedimentation as $90 \%$ of sediment directly flows to the bay without settling within the lake. The silting process is accelerated by the aquatic manifestations.

\section{Inflow from Mahanadi system}

Rivers in the SMD are ephemeral and provide little fresh water flow in summer. The lake receives 5-6\% of flow of Mahanadi system at present instead of $8-10 \%$ in 1990 's. It is due to the diversion of 60 to $70 \%$ of water through Gabakunda Cut to Bay of the river Bhargavi. The river Makara, a small drain prior to 1990's, is active at present and carrying more flow to the lake than the parent river Daya. The delta faced very high peak floods more than 31500 umec in 2001, 2003, 2006, 2008, 2011, and 2014. The years 1995 to 2000 and 2015 to 2017 
were the most vulnerable years for the lake due to prevalence of dry spell in the SMD with a small warm period (peak in 1998). The ever recorded least peak discharge of the basin was 5050 cumec in 2000 at delta head, Naraj.

\section{Sediment transport to lake}

There is long shore drift from SW to NE and transport in average 1.2 cum of sand in the near-shore regime. The average annual suspended load of 2.70 MMT is carried from inland by the Mahanadi to Chilika during the monsoon (Delta Dev. Plan, Orissa, 1986) whereas annual sediment exchange between the lagoon and Bay was 1.0 cum Chandramohan et al. (1991).

\section{Salinity Exchange}

The salinity of the lagoon increases during summer due to evaporation, southern wind and spring tides. It is estimated to rise from 2 to 6,8 to 13 and 9 to 15 PSU in NS, CS and SS respectively. Mohanty et al., 2015 have reported that the salinity of the lake is of fluctuating nature. It manifests the growth of see weeds, aquatic biodiversity. The instability of the TI, proliferation of planktons, weeds growth and salinity change affect the hydrodynamics of the lagoon and changes the salinity gradient. Delayed resiliency of salinity concentration after a monsoon discharge develops the major concern for the management, as salinity is the primary indicator for the eco health of the lagoon. Tidal prism is absent during monsoon flow but during non-monsoon it is $150 \mathrm{um}$. The rate of tidal fluctuation is $1.0 \mathrm{~m}$ in monsoon and $0.2 \mathrm{~m}$ during non-monsoon. The tidal flux during post intervention has improved by $45 \%$. The long shore drift, diurnal tidal fluctuation, and tidal prism govern the salinity of the lake (http://iczmpodisha.org/projectreport/Project\%2 0 Report.pdf).

The average salinity of the lake was 22.3 PSU in 1957.58, 13-20 PSU in 1960-61 and 9.4 -11.8 PSU from 1961 to 1964 and was reduced to average salinity of 8.3 PSU in 1999 (Bando padhyay et al 1991 \& Kadekodi et al (1999). After intervention, the average salinity of the lagoon increased gradually to 13.2 PSU (one PSU $=32.4 \mathrm{ppm}$ or ppt) in 2005. The average salinity was oscillating till 2005 to 2015 in flood years (2004, 2006, $2008 \&$ 2014) The average salinity was less than the previous years as the lagoon receives its flushing flood and residence time changed.

The sectorial salinity data (1999 to 2015) indicates that the salinity of all the sectors was declining 4 to 10 PSU from 2008 onwards after the historical flood of 44750 umec in 2008. The basin is running with a dry spell (2014-2017) at present. Barrages, fall in rainfall in the upper Mahanadi basin have declined annual runoff from the Mahanadi delta, which is under the constraint of flow and paucity of sediment. The continuous depletion of quantum of flow, rise of surface temperature of the lake and plunge in average salinity has affected its eco-health (Fig. 6).

\section{Saline Embankments}

Saline embankments of length $246.7 \mathrm{~km}$ were constructed and maintained by the W.R. Dept. Odisha to save the island from distortion and its islanders from flooding. It was 232.19 $\mathrm{km}$ before intervention, which hinder free discharge to the sea and encroaching flood plain. 


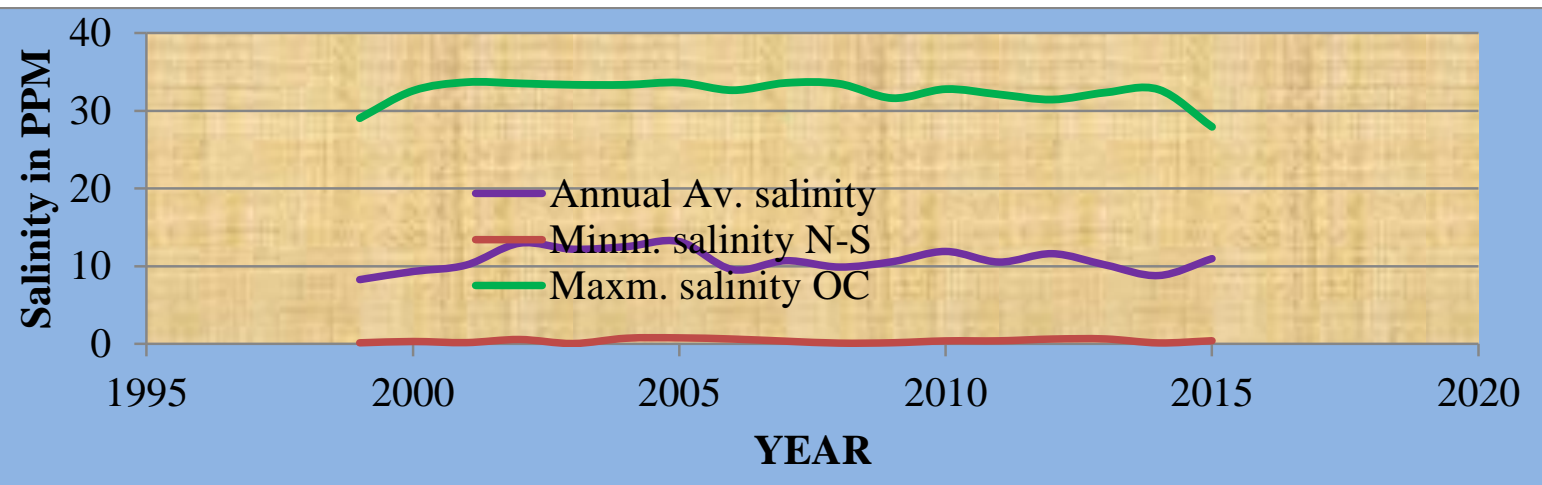

Figure 6: Maximum, Minimum and average salinity of the Chilika from (1999 to 2015)

\section{Lake dimensions}

In 1984 the lake area was $1027 \mathrm{~km}^{2}$. Tripathy 1995 reported the lake depth was 2.5 $\mathrm{m}$ in SS and maximum $3.4 \mathrm{~m}$ in CS in 1990. Dry spell prevailed in the Mahanadi basin 1985 to 1999 and also ENSO activities. The lake was deprived of flushing flood except 1992. There was irregular silting and sedimentation was accelerated up to 2000 . The $\mathrm{N}$-sector observed to be the shallowest with depths ranging from $0.2 \mathrm{~m}$ to $1.5 \mathrm{~m}$ and in central sector the depth varies from $1.5-2.5 \mathrm{~m}$. The central sector after dredging has increased depth of maximum $6.0 \mathrm{~m}$ whereas southern sector has depth of 2.5-3.5 m. (CDA Report 2012-13). Panda et al.,2008 reported the minimum area to shrunk Chilika in 2008 was $690 \mathrm{~km}^{2}$ (from Sahu et al 2014). The water levels in the lagoon during SWM are higher in average by $1.22 \mathrm{~m}$ as compared to summer.

\section{The water spread area}

The water spread area of the lagoon was $1165 \mathrm{~km}^{2}$ during flood and 906 sq.km during summer (Sterling 1848). Gupta 2014 reported minimum water spread area as $865 \mathrm{~km}^{2}$ during 2014. CDA in its health card reported the lagoon had water spread area $824 \mathrm{~km}^{2}$ in 1972Journal of Wetlands Environmental Management Vol 7, No 1 (2019) 1 - 22 http://dx.doi.org/10.20527/jwem.v7i1.186
73 and in 2000 it was reduced to $790 \mathrm{~km}^{2}$. Panda et al., 2008 reported that the spread area has been reduced to 690sq.km. The water spread area of the lake varies daily and seasonally. During diurnal daily tides water spread area of Chilika varies from 720 to $846 \mathrm{~km}^{2}$ in low and high tides respectively (Gopi krishnan, 2014)[28]. Extreme meteorological events i.e. severe cyclonic storms, Tsunamis, eclipses and very high floods etc can abruptly changes the water spread area. Maximum and minimum depth (in cm), salinity, rainfall, aqua catch and ENSO activities information of Chilika lagoon are given in Table 1.

\section{The islands and isles of $\mathrm{OC}$}

The106 numbers of islands of 203Sq.km that contribute about $17 \%$ areas (CDA report). They decide the Lake Stratigraphy, geomorphology and ecology. Islands are continuously in the process of either building or dispersing. The sand spits and islands close to S-sector have permanent habitation. Isles in O.C. (flood deltas) govern the mouthing activities and tidal prism and no habitation. They restrict/enhance flow that influence the resident time of the lake, which is 132 days during monsoon and 4-5 days in non-monsoon. 
Table 1. Maximum and minimum depth (in $\mathrm{cm}$ ), salinity, rainfall, aqua catch and ENSO activities in Chilika lagoon.

\begin{tabular}{|c|c|c|c|c|c|c|c|c|c|}
\hline Year & $\begin{array}{l}\text { Max } \\
\text { depth } \\
(\mathrm{cm})\end{array}$ & $\begin{array}{l}\text { Min } \\
\text { depth } \\
(\mathrm{cm})\end{array}$ & $\begin{array}{c}\text { Av. } \\
\text { (appx) } \\
\text { salinity } \\
\text { in PPT }\end{array}$ & $\begin{array}{l}\text { Flow } \\
\text { SMD to } \\
\text { Chilika } \\
\text { (cumec) }\end{array}$ & $\begin{array}{c}\text { Area } 31^{\mathrm{st}} \\
\text { Dec } \\
(\mathrm{Sq} . \mathrm{km})\end{array}$ & $\begin{array}{l}\text { Rainfall } \\
\text { in } \mathrm{mm}\end{array}$ & $\begin{array}{l}\text { Aqua } \\
\text { catch } \\
\text { (MT) }\end{array}$ & $\begin{array}{c}\text { Meteorological } \\
\text { Extremes/Flood/ } \\
\text { storm/ENSO/ } \\
\text { drought/Tsunami }\end{array}$ & Source \\
\hline \multicolumn{10}{|c|}{ Pre interventions } \\
\hline 1988-89 & 330 & 50 & 8.2 & 761 & 967 & 1270.5 & 6172 & Strong La Niña & Adhikary et al -92 \\
\hline $1989-90$ & 300 & 20 & 7.3 & 560 & 954 & 1283.9 & 6706 & SCS (T6.5) GPL & Sahu et al.,2014 \\
\hline 1990-91 & 340 & 20 & 7.8 & 2040 & 950 & 1865.8 & 4297 & VSCS(T 6.5) & Rajat et al 2012 \\
\hline $1991-92$ & & & 4.1 app & 2627 & 1008 & 1465.7 & 4586 & La Nada (Neutral) & Rajat et al 2012 \\
\hline $1992-93$ & 340 & 74 & 6.0 & 2464 & 984 & 1344.1 & 4173 & La Nada (Neutral) & Ghosh et al. 2003 \\
\hline $1993-94$ & 210 & 65 & 8.0 & 1522 & 995 & 1421.6 & 3496 & La Nada (Neutral) & Ghosh et al. 2003 \\
\hline $1994-95$ & 332 & 58 & 11.0 & 1895 & 994 & 1700.2 & 1418 & 4-MF, Mod El Niño & Ghosh et al. 2003 \\
\hline $1995-96$ & 382 & 60 & 4.2 & 1473 & 999 & 1739.3 & 1274 & VSCS Gopalpur & Ghosh et al. 2003 \\
\hline $1996-97$ & 142 & 42 & 5.1 & 747 & 967 & 1042.4 & 1645 & La Nada (Neutral) & Ghosh et al. 2003 \\
\hline 1997-98 & 189 & 72 & 4(app) & 1363 & 955 & 1493.0 & 1652 & Very strong El Niño & P. S. Edwards \\
\hline $1998-99$ & 480 & 40 & 4.0 & 1294 & 942 & 1277.5 & 1702 & Strong El Niña & Ghosh et al. 2003 \\
\hline 1999-00 & 330 & 35 & 8.28 & 1015 & 950 & 1435.7 & 1746 & SC/VSCS GPL & Ghosh et al. 2003 \\
\hline 2000-01 & 677 & 28 & 9.32 & 285 & 1025 & 1022.9 & 4983 & Weak La Niña & Ghosh et al. 2003 \\
\hline \multicolumn{10}{|c|}{ Post Intervention } \\
\hline $2001-02$ & 540 & 31 & 10.15 & 2254 & 1013 & 1005.5 & 1611 & High flood & Ghosh et al. 2003 \\
\hline $2002-03$ & 586 & 29 & 12.96 & 940 & 1011 & 1658.7 & 11989 & Mod El Niño & Ghosh et al. 2003 \\
\hline 2003-04 & NA & NA & 12.19 & 2160 & 1025.7 & 1273.6 & 10894 & High flood & W R Dept. Odisha \\
\hline 2004-05 & NA & NA & 12.51 & 1226 & 1047.8 & 1519.5 & 14053 & Sumatra Tsunami & IMD Report \\
\hline $2005-06$ & 420 & 38 & 13.17 & 1445 & 989.6 & 1682.7 & 13260 & Weak La Niña & CDA report \\
\hline $2006-07$ & 350 & 35 & 9.57 & 2053 & 1012.3 & 1490.0 & 12225 & High flood & Panigrahi et al -07 \\
\hline 2007-08 & 620 & 235 & 10.71 & 1188 & 997.5 & 1498.6 & 9956 & Strong la Niña & CDA Report \\
\hline 2008-09 & 682 & 28 & 9.89 & 2531 & 1014 & 1550.3 & 10047 & History flood & Jeong et al. 2008 \\
\hline $2009-10$ & NA & NA & 10.58 & 1384 & 956.2 & 1576.0 & 10702 & Mod. El Niño & http://ggweather.com/enso/oni.htm \\
\hline $2010-11$ & NA & NA & 11.90 & 1103 & 1005.1 & 964.00 & 11955 & Strong La Niña & \\
\hline $2011-12$ & NA & NA & 10.54 & 2185 & 997.7 & 1275.1 & 13066 & HF Mod La Niña & W R Dept. Odisha \\
\hline $2012-13$ & 620 & 38 & 11.61 & 1082 & 997.70 & 1932 & 14228 & La Nada (Neutral) & CDR 2012-13 \\
\hline $2013-14$ & NA & NA & 10.17 & 1149 & 10117 & 1524 & 12936 & VSCS/High flood & IMD F/C \\
\hline $2014-15$ & NA & NA & 8.80 & 1781 & 997.00 & 892 & 12963 & VSCS Hudhud & IMD F/C \\
\hline $2015-16$ & NA & NA & 10.98 & $<1120$ & 1021.5 & 954 & & Very strong El Niño & http://ggweather.com/enso/oni.htm \\
\hline $2016-17$ & 420 & 38 & & $<1120$ & 971.00 & 1140.0 & & Weak La Niña & \\
\hline
\end{tabular}




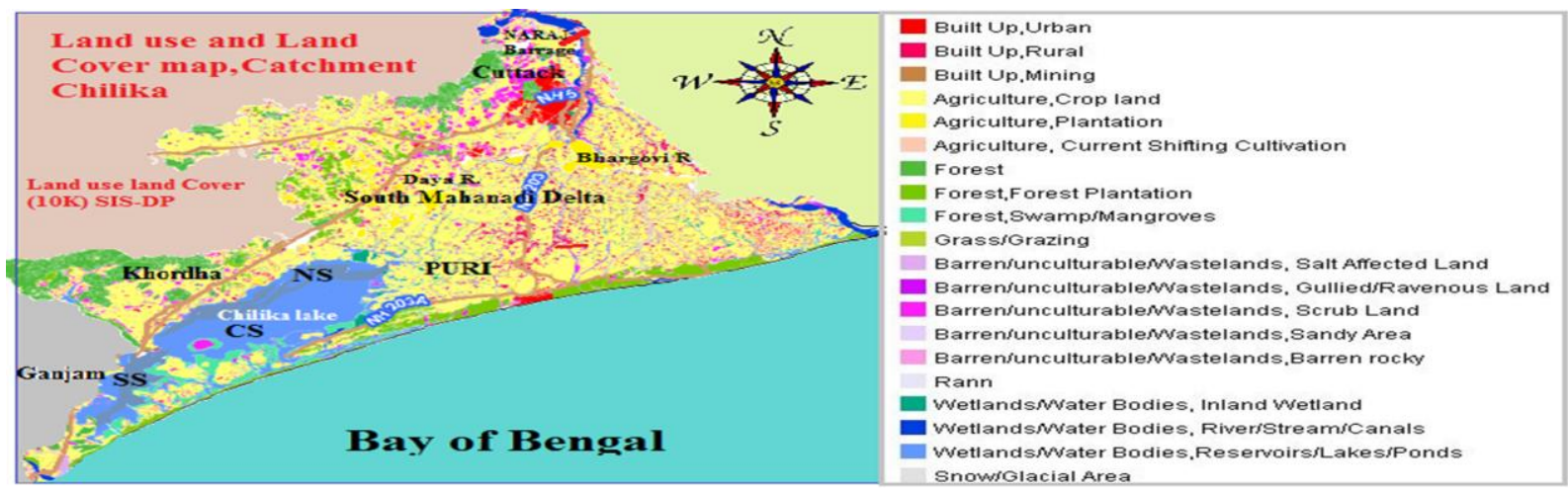

Figure 7. LU/LC map of Catchment with Chilika lake (http://bhuvan.nrsc.gov.in/gis/thematic/index.php)
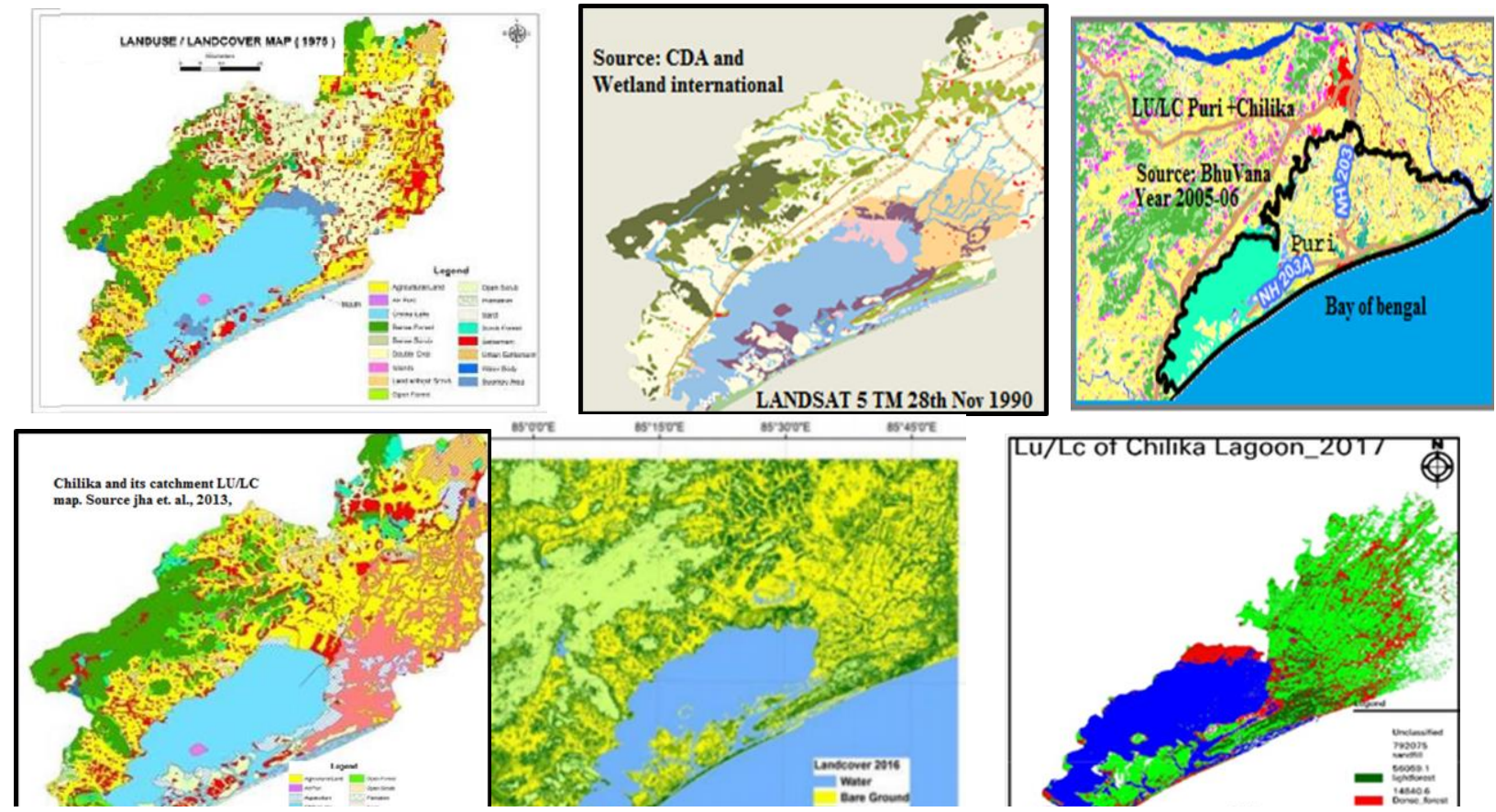

Figure 8. LU/LC Chilika Lake and catchment year 1975, 1985, 1990, 1999, 2011, 2013 and 2017 (Wetland international South Asia and CDA and Jha et al., 2013, 1987 and in Mishra and Das 2017)

Edaphic factors of some Islands are small hillocks and others made up of fine-grained sand overlain by the swampy mud flats. The isles migrate in any direction or remain

delta near the shoreline by the surplus sediment near an inlet and the wave dynamics with Aeolian process triggers their deposit. Slow emergences build and emergence shatters the dunes.

\section{Land forms}

The changes in Land use and land Journal of Wetlands Environmental Management Vol 7, No 1 (2019) 1 - 22 http://dx.doi.org/10.20527/jwem.v7i1.186 
satellite imageries using the RESOURCESAT 1 (IRS-P6) continuity mission to IRS- 1C/ 1D. A comparative study is given in Fig -9 . Generally the land use and land cover data of the terrain in the catchment of Chilika is available from Landsat - 7 up to 2012-13. It is observed that the Land Sat images are received noisy and there is di-striping of Image beyond 2013 to 2017. So it is difficult for analysis of the data. Noise from the Satellite picture is eliminated radiometric correction (Focal analysis). The identification of data was done as per LULC, 50K, ORISSA, NRSC, ISRO, Thematic Services, Version 2, Vector data, Bhuvan, as per NRSC data dissemination policy (Fig. 7).
The sandy islands exists along the coast from Satapada extends up to $36 \mathrm{~km}$ towards NE. The barrier spits are of recent formation (500 years). But the associated sand dunes all along the coast are 1300 to 2200 years old and young alluvial plains are paddy cultivated areas (granary) with major plantations are coconut and thickly populated Jhanu trees (Tamarix dioica). The recent alluvial plains are water logged areas have intermittent paddy fields covered with sweet water aquatic plants like Water Hyacinth and Ipomeas and other planktons. The west coast was filled with many phyto-planktons, Nala grass (Local name) and sea grasses augmenting the sedimentation process of the lake. The sandy beaches, islands and barrier spits were covered with mangroves,

Table 2. The type of land use during pre and post interventions in the period 1999-00, 2005-06 and 2011-12

\begin{tabular}{lllllll}
\hline \multirow{2}{*}{ Type of land use } & \multicolumn{2}{c}{1999} & \multicolumn{2}{c}{$2005-06$} & \multicolumn{2}{c}{$2011-12$} \\
\cline { 2 - 7 } & \multicolumn{1}{c}{$\mathrm{km}^{2}$} & \multicolumn{1}{c}{$\%$} & $\mathrm{~km}^{2}$ & $\%$ & $\mathrm{~km}^{2}$ & $\%$ \\
\hline Total Area & 3479.00 & 100.00 & 3479.00 & 100.00 & 3479.00 & 100.00 \\
Agricultural Land & 1755.24 & 50.45 & 1755.24 & 50.45 & 1700.87 & 48.89 \\
Chilika Lake & 900.95 & 25.90 & 900.95 & 25.90 & 894.49 & 25.71 \\
Forest (all types) & 167.78 & 4.82 & 168.58 & 4.85 & 169.81 & 4.88 \\
Settlement & 289.55 & 8.32 & 290.45 & 8.35 & 291.62 & 8.38 \\
Water Body (all) & 263.19 & 7.57 & 262.59 & 7.55 & 269.58 & 7.75 \\
Others & 102.29 & 2.94 & 101.19 & 2.91 & 152.63 & 4.39 \\
\hline
\end{tabular}

The land cover in and around the Chilika depends upon the soil characteristics and the salinity of the water of the lake which is further a function of the residence time and decadal summer surface water temperature (SSWT) rise trend is $0.39^{\circ} \mathrm{C}$ Ralei M O C (2009). The residence time is in maximum 132days in northern sector during summer and 35days in southern sector in rainy season Mohanty et al (2016). The change in the dimension of the TI, and impact of meteorological extremes in the SMD, the anthropogenic Eco destruction like devastation of mangrove forests, Gherry bundh's, dredging of depleted channels, proliferation of algae/phyto-planktons, ipomeas 
and water hyacinths were the causes for changes in LU/LC of the lake.

The exposed strings of mudflats are abundance with the marine fauna (crabs, fish, algae, polychaetes, molluscs, crustaceans, etc.). The lake lies on the migratory Pala- arctic flyway, sustain regular visit of about 0.7-1.0 million avifauna annually (both migratory and country). Lake ecology refurbished with fish

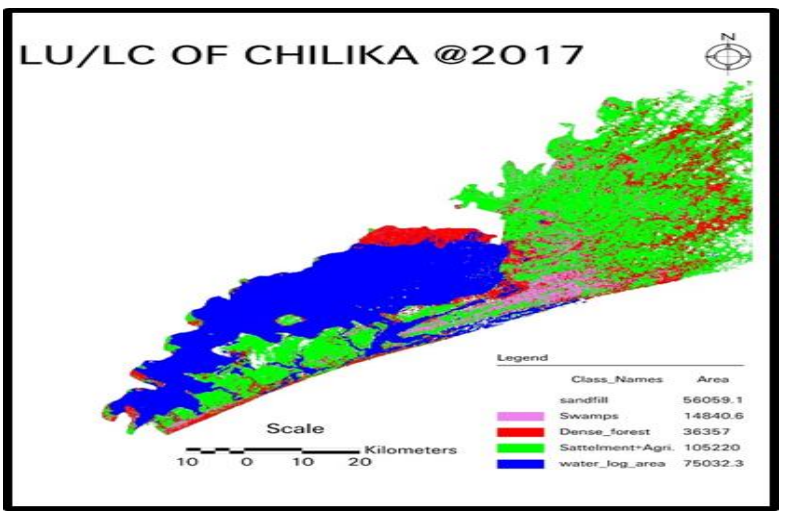

catch from 1352 MT in 1996 to 14,228 MT in 2012, Irrawaddy dolphin from 70 (2003) to 152 number in 2013, increase in tidal flux 0.36 to $0.52 \mathrm{~m}$ and decrease in stratification of phytoplanktons, Ipomeas and water Hyacinth. The wet land support live hood to. 23 million lake users out of which $45 \%$ are native fishermen residing inside the lake. (CDA report 2012-13).

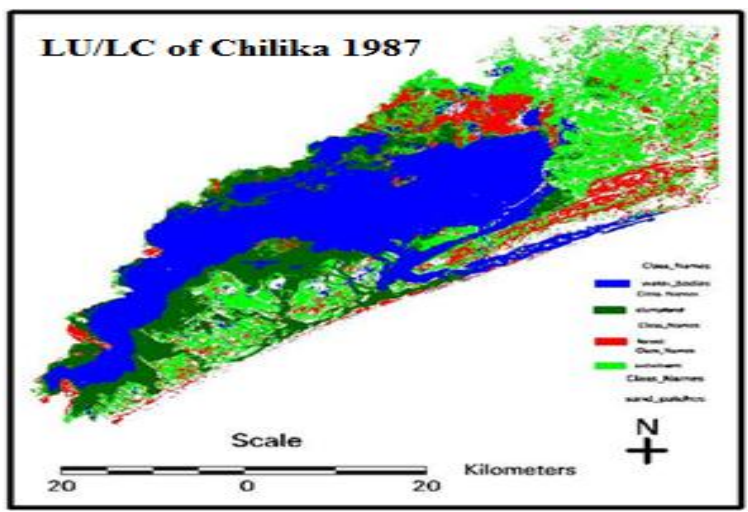

Figure 10. The GIS figures of Chilika Lake and south Mahanadi delta for the year 1987 and 2017

The area taken for study and identification of images and color coding procedures are different for different researchers. The greenness and water spread area are different seasonally and after each meteorological extreme event are also different. Hence the results reported by GIS visuals may vary from the actuals in the fields.

The GIS imagery of 1975and 1999 (preintervention) reveals that , the agricultural land were $(34.84 \%)$, water body $(19.2 \%)$, settlement $(10.6 \%)$ and Forest area $(9.3 \%)$, land without scrub $(4.5 \%)$ and the swamp area reduced drastically from $2.65 \%$ to 0.24 in the periphery of the lagoon in NW fringe The results were compared with the GIS analysis of the same area in 2012 and the changes are given in Table 5), Ojha et al 2013 (Table 3).

Onam B 2006 reported that the geomorphic features in the SMD around Chilika lake were deltaic plain $238.24 \mathrm{~km}^{2}$, Flood plain, levee and ridges $16.22 \mathrm{~km}^{2}$, Paleo and abandoned drainage channels $57.92 \mathrm{~km} 2$,buried channels,/Pediment $142.94 \mathrm{~km} 2$, Mud flat $483.34 \mathrm{~km} 2$, lateritic upland $71.05 \mathrm{~km} 2$ and others hills and valleys etc were $9.80 \mathrm{Km}^{2}$. Paul et al. (2014) estimated the geographic features of the South Mahanadi delta has young and recent delta alluvial plains $1963.77 \mathrm{~km}^{2}$, Water spread area of lagoon including swamps $884.80 \mathrm{~km}^{2}$, Coastal plains $320.67 \mathrm{~km}^{2}$, Barrier spit $23.06 \mathrm{Km}^{2}$ and old/recent barrier spit up to Puri is $310.68 \mathrm{Km}^{2}$.

Journal of Wetlands Environmental Management

Vol 7, No 1 (2019) 1 - 22 
The analysis of the received imageries bodies has decreased during last 40years shows that the gross agricultural area, water whereas the prominent land use has increased

Table 3. Change in vegetation, water spread area and settlement in study area by the present and other authors

\begin{tabular}{|c|c|c|c|c|c|c|}
\hline No & Study area & Year & $\begin{array}{l}\text { Agricultural } \\
\text { Area / \% of } \\
\text { total area } \\
\mathrm{Km}^{2}\end{array}$ & $\begin{array}{l}\text { Area of lagoon } \\
\text { (water body) } \\
\% \text { of total area } \\
\mathrm{Km}^{2}\end{array}$ & $\begin{array}{l}\text { Settlement rural } \\
\& \text { Urban } 1 \% \text { of } \\
\text { total area } \\
\mathrm{Km}^{2}\end{array}$ & Reference \\
\hline \multirow[t]{3}{*}{1} & Chilika & 1975 & $879.53 / 18.18 \%$ & $1034.1 / 21.4 \%$ & $654.77 / 13.54 \%$ & \multirow{3}{*}{$\begin{array}{l}\text { Ojha A., Rout J., } \\
\text { et. al., (2013) }\end{array}$} \\
\hline & +SMD & 1999 & $910.48 / 18.81 \%$ & $1686.1 / 34.3 \%$ & $1004.3 / 20.75 \%$ & \\
\hline & & 2012 & $887.4 / 18.38 \%$ & $1257.3 / 26.0 \%$ & $1097.6 / 22.74 \%$ & \\
\hline \multirow[t]{2}{*}{2} & Chilika & 1999 & $127.68 / 27 \%$ & $146.60 / 31 \%$ & $141.87 / 03 \%$ & \multirow{2}{*}{$\begin{array}{l}\text { Rout J.,2012,8 km } \\
\text { from coast line }\end{array}$} \\
\hline & area & 2013 & $92.69 / 19.6 \%$ & $140.92 / 29.8 \%$ & $25.064 / 5.3 \%$ & \\
\hline \multirow[t]{4}{*}{3} & $\begin{array}{l}\text { Puri dist. } \\
+ \text { Chilika }\end{array}$ & 1987 & $\begin{array}{l}\text { Tot area taken } \\
=10799\end{array}$ & $856.94 / 7.94 \%$ & $498.87 / 4.62$ & $\begin{array}{l}\text { Present study(Fig- } \\
\text { 10) }\end{array}$ \\
\hline & & 2004 & $1755.2 / 50.45$ & $900.95 / 25.90 \%$ & $289.6 / 8.32 \%$ & http://bhuvan.nrsc. \\
\hline & & 2011 & $1700.9 / 48.89 \%$ & $894.49 / 25.71 \%$ & $291.62 / 8.38 \%$ & $\begin{array}{l}\text { gov.in/gis/thematic } \\
\text { /index.php\# }\end{array}$ \\
\hline & & 2017 & $\begin{array}{l}\text { Tot area taken } \\
=10996\end{array}$ & $750.32 / 6.58 \%$ & $1052.2 / 9.57 \%$ & $\begin{array}{l}\text { Present study(Fig - } \\
\text { 10) }\end{array}$ \\
\hline \multirow[t]{2}{*}{4} & Chilika+ca & 1987 & $1302 / 21.2 \%$ & $999 / 16.3 \%$ & DNA & Goswami et al., \\
\hline & tchment & 2016 & $1187 / 19.35 \%$ & $860 / 14.02 \%$ & DNA & 2017 \\
\hline 5 & $\begin{array}{l}\text { Chilika+ca } \\
\text { tchment }\end{array}$ & 2016 & $1840.9 / 35.13 \%$ & & & $\begin{array}{l}\text { Sk. Majharul Islam } \\
\text { et al., } 2009\end{array}$ \\
\hline
\end{tabular}

by urbanization, swamp area and the reserved and the unreserved forest in the catchment area. Last 25 years the lagoon has decreased its water spread area, agricultural area and swamps at the sacrifice of habitation, sands and shrimp culture, which is the deteriorating factors for the Lake. The land use and land cover of the Chilika Lake and the connected the Mahanadi catchment and Western catchment from the studies of various authors have been studied $200 \mathrm{~km} 2$ of the lagoon area in the northern sector is infested with Nalagrass which is of high fibre content (Jaykumar et. al., 2011)
The impact of the changes in the barrier spit, TI's and the outer channel configuration has maximum in the peripheral blocks of Puri district i.e. Puri Sadar, Sakhigopal, Krishna Prasad, Brmhagiri, Pipili, Delang and Kanas. Present study has excluded the upper deltaic zone of the south Mahanadi delta and analyzed the TM imagery of the lower SMD and the Chilika lagoon and the results were given in Table 6.

\section{RESULTS \& DISCUSSION}

After studying the GIS and Land Sat series from Glovis classic (Landsat Series Thematic 
mapper -5) of Google of the barrier spit, outer channel, spread of Chilika lagoon the following inferences are drawn:

1. Chilika barrier spit is divided into stable towards south and fragile to north.

2. Stable barrier spit is continuous and are land connected, least affected by erosion and accretion, wider barrier spits. Sand dunes of the barrier islands are coast perpendicular. The beach length is narrow in the south and wider towards north.

3. The unstable barrier spits in north is approachable through the outer channel. The spit geometry is ever changing and the tidal inlets within are nomadic and observed continuous oscillatory propagation to north.

4. The swamps in the NW fringe of $\mathrm{N}$ sector of the lagoon is dried up and converting gradually to agricultural land.

The Report of the Fact Finding Committee on Chilika Fisheries Submitted to Orissa High Court on 16.8.1993 depict that the lake Chilika was shrunk by $393 \mathrm{~km}^{2}$ during 1920 to 1993 (Pattanaik S., 1993). The evolution of this land mass in the central sector on the foot hills of Eastern Ghats hills range mostly converted either as agricultural land or homestead land. Similarly, a large portion of northern sector of the lake is being used either as prawn culture or agriculture. The construction of Gobardhanpur Barrage has stabilized or created an area of ten thousand hectares of marsh to irrigable land. A part of such land is from the swamps and mud flats of the lagoon. (W. R. Dept., Odisha 2014).

The lake has very strong prolific ecosystem that protract the livelihood of more than 0.23 million fishermen and 0.8 million stake holders in the region. Ramble in population are the districts Puri, Khordha and Ganjam in and around Chilika lagoon. But the growth in yield is not synchronous with the hike in population. The people has changed their land use pattern and explored the non-habitable area to habitation. GIS studies reveal that in the local catchment area of the lake, the agricultural land use was trim down from 42.86 to $31.94 \%$ to accommodate as home stead land (Both rural and urban), swamp area and shrimp culture area. After hydrological interventions the swamp area and agricultural land has decreased at the cost of human settlement and shrimp culture within the lake.

Results of observations for major sediment flow to the lagoon via the rivers Daya and Bhargavi during monsoon months has been taken for the period both pre and post Naraj barrage period. (Table 3). From data analysis it is found that the rate of flow to the lagoon has improved with regulatory operational procedure of the barrage. But it is found that the $\%$ of carriage of silt has increased in River Bhargavi than the river Daya.

As per the AWIFS studies the months under consideration are Jan (Post monsoon), May (pre monsoon) and August (active monsoon) for the period 2004-2012. The corresponding monitoring of NSRC imageries have provided the average water spread area post barrage period is $777.7 \mathrm{Km}^{2}$ excluding swamps, mud flats and raised islands. Similarly the average total area of the lake has been found as 1010.6 sq.km including swamps and mud flats Excluding the spits and sand bars of the coast. The average perimeter of the water spread area of the lake has been evaluated as $458.7 \mathrm{~km}$. Pre barrage and pre Official mouth scenario as per the report of Chilika Development Authority was 790 sq.km, 1045 
sq.km for the average water spread area and average lake area. The result obtained can be compared with evaluated results of Gupta et al., (2008) maximum water spread area to be 1020 sq.km and minimum in summer to be $704 \mathrm{sq} . \mathrm{km}$. The increase in the water spread area was due to the opened active mouth at Dahalabali in front of Sanapatna.

Dredging of TI of lagoons frequently is used for improving the water quality. When it is carried out without prediction modeling and scientific study, can sometimes have negative impact of destruction to benthic habitats and deterioration water quality (Kennish, 2012). Anthropogenic interventions to the natural ecosystem subject to judicious scientific background may affect its habitats and ecosystem. Dredging of Sipakuda TI (2000) after 17years of excavation is in controversy. The TI has improved the lagoon character, salinity gradient, fishery wealth but could not sustain as a permanent solution to Chilika's health. The dredged TI made the lagoon stable for only 8years but the fragility character of the barrier spit prevailed after 2008 .

The Gherri bundhs or the saline embankments in and around the lake area have obstructed the natural flow. These high lands are the flood plains of the lake, which were absorbing the flood stress. The average perimeter of the lake $458.7 \mathrm{~km}$ and $54 \%$ of it was protected from natural flow. Consequently, the flow is channelized, the swamps and mud flats in the NE sector are retrieved for agriculture constructing the Gobardhanpur barrage. Gabakund barrage has diverted 50\% flow of river Bhargavi to sea at its middle reach. The tail end of the river has dried up, reducing flow. The effect of Gherri Bundhs on the health of the lake needs to be studied.
The Pearson's Chilika bathymetry Chart (1848) indicate the depth of the lake is maximum at the tidal inlet of about 4.5 to 4.88 $\mathrm{m}$, the depth of lake in northern sector was varying from 0.6 to $1.5 \mathrm{~m}$, the central sector was having depth 2-3 $\mathrm{m}$ whereas the southern sector having depth $2-4 \mathrm{~m}$. The present bathymetry map of the lake prior to hydrologic interventions has shown that the lagoon is depleting. However, after hydrological interventions with flushing flow the lake has retrieved and presently maintaining the status of 150 years back.

In the southern spits where the sand dunes were shore perpendicular, a number of hydrologic shifts were seen, the last shift is near Jahnikuda. These disseminating points are almost symmetrical in nature and moving from south to north. These shifts represent the age of the lagoon. From the land pattern it can be predicted that this hydrologic triple point may shift somewhere near Gabakund in future.

\section{CONCLUSIONS \& RECOMMENDATIONS}

Keeping pace with the changing climate and weather, the migration of the TI's to north, in the hydraulics and anthropogenic interventions shall invite threat to the lake ecosystem by:

1. The Chilika Lagoon exhibit semi cyclic character from choked to restricted. Pre barrage it was choked with single depleted inlet but post barrage period it is now restricted with multiple inlets.

2. Tidal inlets migrate northward. Opening of mouths may be associated with storm surges, triggered by solar eclipses, There is retrogression of coast towards sea. The shifting/migration of inlet towards 
north assured and the biology have improved than that of two decade past.

3. The depleted salinity of the lagoon had improved till 2008 and then onwards started decreasing and the rate of decrease has observed more from 2014.

4. Sediment transport to the lagoon through major inflowing rivers Daya and Bhargavi have decreased due to construction of Naraj barrage. The concentration of sediment transport to the lagoon is more in Bhargavi River than the river Daya.

5. The AWIFS monitoring of NRSC shows the average minimum water spread area without islands is 777 sq.km and the average overall area including swamps and mudflats is $1011 \mathrm{sq} . \mathrm{km}$. The minimum and the maximum water spread width during post barrage are $3 \mathrm{~km}$ and $27 \mathrm{~km}$ respectively. The coastal length is $66 \mathrm{~km}$ whereas the outer channel length is $30 \mathrm{~km}$. The water spread area and the overall area during pre-monsoon and monsoon period depends upon the spring tides and the amount of input flood respectively of that year.

6. The islands in the southern sector and central sector exhibit minimum geomorphic changes after construction of barrage whereas the islands in the outer channel are constantly changing in dimension and are due to shifting of inlet and their flood and Ebb deltas.

7. The construction of the Gabakund cut have reduced the flushing flow to the lagoon since it is opened 1987 onward diverting major flow of Bhargavi River directly to sea and depriving the Chilika lagoon to get its flushing velocity and flow during floods.

\section{ACKNOWLEDGEMENT}

We thankful that the research was supported by World Bank funded CDA-ICZMP project. Also, we thankful to Water Recourse Dept. for providing relevant information in partial fulfillment of this research. We are grateful to Chief Executive CDA and scientific Officer CDA for facilitation and accomplishment of the research. We also sincerely acknowledge the colleagues and support staffs those who helped in this research.

\section{REFERENCES}

Abinash kumar (2014). "Spatial and temporal variation of total suspended sediment concentration in Chilika lagoon using modis/terra data" , Department of Mining Engineering, National Institute of Technology, Rourkela.

Andrew sterling (1846): "Orissa, its geography, statistics, history, religion and antiquities. "John Snow, 35 Paternoster Row, sold by Brooks, Leicester, Noble, Boston 1846. Source: British library.

Audin J.B. (1950). " Some factors concerning the transport of sediment by rivers", Superintending Geologist, Geological Survey of India, Calcutta. Volume XVI-No. 6.

Bandyopadhyay S., Gopal B (1991). Ecosystem studies and management problem of coastal lagoon, the lake Chilika in Ghosh A. K. and Pattanaik A. K., Chilika lagoon experiences and lessons learned in brief pp-120, 
http://www.worldlakes.org/uploads/08_chil ika_lagoon_27february2006.pdf.

Bharathi M.D., Patra Sivaji, Sundaramoorthya S., Madeswarana P., Sundaramanickamb A. (2017). Elucidation of seasonal variations of physicochemical and biological parameters with statistical analysis methods in Puducherry coastal waters, Elsivier, Science Direct, Marine Pollution Bulletin Vol. 122, pp- 432-440.

Chandramohan, P. (1993). "Coastal processes at the shore front of Chilika lake, East coast of India" Indian Journal of marine Sciences, Volume $21 \quad \mathrm{P} \quad$ 268-272

Chilika Development Authority Report (2013). "The annual report Chilika Development authority 2011-12 and 2012-13" (unpublished).

Cotton F. C. (1858). "Report of a professional tour of inspection by Lt. Colonel F. C. Cotton on $12^{\text {th }}$ July 1856 " Fort St. George, Para 78 G.R. (Unpublished).

Das B.P., Jena J. G.: (2007). "Impact of Mahanadi basin Development on Ecohydrology of Chilika lake" Proceeding of TAAL 2007: The $12^{\text {th }}$ world lake Conference $-697-702$.

DPR CDA (2013):" Annual report Chilika Development authority 2006" Chilika Development Authority, Government of Orissa (unpublished).

Ghosh Asish (2003). Experience brief for Chilika lake, Orissa, India" Center for environment and development, 22, Oct, 2003.

Ghosh A. K., Pattnaik A. K. (2008). Chilika Lagoon Experience and Lessons learned brief , UNEP International Waters Learning
Exchange and Resource Network. pp. p.115. Retrieved 2008-12-23.

Gopi Krishna, B. et al (2014). "Impact of salinity of Chilika lake due to changes in inlet system", Indian Journal of Marine Science, Vol. 43 (7).

Goswami S., Vive G., Choudhury S. B. (2017). Three decades of land cover change in Chilika and its neighbourhood area using 30m landsat data, https://www.researchgate. net/profile/ Santonu_Goswami/publication/320752260 _links/ 59f923670f7 e9b553ec 0ccbb / pdf .

Gupta G.V. M, et al (2008). "Influence of net ecosystem metabolism in transferring riverine organic carbon to atmospheric $\mathrm{CO}_{2}$ , in a tropical coastal lagoon (Chilika Lake, India), Biochemistry, Vol- 87, pp. 265-285.

Gupta M. (2014):" Tidal induced geometrical changes in Chilika lagoon using remote sensing", Current Science, Vol.107, No 1 PP- 63-67.

Harrish; J. C., Young C.B. : (1860) “ Captain Harrish report on Mahanadi Flood protection survey works" correspondences between the Chief engineer and superintending Engineer and Executive engineer, lower provinces 1858 to 1860 , source Water Resources (Dept. Library Odisha).

Irrigation Deptt. Orissa (1986): "Mahanadi Delta development plan on Mahanadi delta command area" Reoport of Puri Investigation Division, Puri. (Unpublished)

Islam M. Sk (2013):'Mapping coastal land forms at the interface of the sheltered lagoon and open marine environment", Journal of Radix International Educational and Research Cosortium, Vol-2 Issue 10 
pp-1-10

Islam Sk M., Sengupta A., Kamila1 A., Jana S., Paul A. Kr., 2016, Monitoring the Agricultural Land of Chilika Watershed using Satellite Images, Journal of Coastal Sciences, Vol 3(1), Page 26-36

Jalli S. Ku., Balabantaray S.K. and Mishra A. $\mathrm{Ku}$., 2016, Analysis of trophic state index of Chilika Lake during pre and post monsoon season using in-situ and landsat-8 data observations, Oct. Jour. Env. Res. Vol. 4(4): pp-282-298.

Kadekodi G. K., Gulati S.C., 1999, Root causes of biodiversity losses in Chilika Lake, CMDR Monograph Series, No. - 26,pp 0124.

Kadekodi, G. K. and Gulati, S. C. (1999): "Root causes of Biodiversity losses in Chilika Lake", CMDR monograph series, No-26.

Kennish, M. J. (2012). Environmental threats and environmental future of estuaries. Environmental Conservation, 29(1): 78-107. http://dx.doi.org/10.1017/S0376892902 000061.

Lal N. K. et al (2009):" Evolution of East Coast of India - a plate tectonic reconstruction" Jour. Geological Society of India, Vol 73, Feb 09, P- 249-260.

Lo, C.P. and Yang, X., 2002. Drivers of landuse/land-cover changes and dynamic modeling for the Atlanta, Georgia metropolitan area. PE \& RSPhotogrammetric Engineering \& Remote Sensing, 68(10), pp.1073-1082.

Mahalanobis P. C. (1928):"Mahalanobis Report" Irrigation and power dept., Orissa. Source: Water Resources (Dept. Library Odisha).
Mahalik N.K. et al (1996): "Geomorphology and evolution of the Mahanadi delta, India", Journal of Geoscience, Vol-39(6) pp- 111122.

Mahanty M.M., Mohanty P.K, Pattnaik A.K., Panda U.S., Pradhan S., Samal R.N. , 2016, Hydrodynamics, temperature/salinity variability and residence time in the Chilika lagoon during dry and wet period: Measurement and modeling, Continental Shelf Research, Vol- 125, pp-28-43.

Mahanty M.M., Mohanty P.K., Pattnaik A.K., Panda U.S., Pradhan S, Samal R.N., 2016, Hydrodynamics, temperature/salinity variability and residence time in the Chilika lagoon during dry and wet period: Measurement and modeling, Continental Shelf Research. Vol-125, pp28-43, http://dx.doi.org/10.1016/j.csr.2016.06.017

Mishra S. P. and Jena J. G., (2015) "Intervention of Naraj Barrage: Its effects on sediment inflows into Chilika Lake, India", Lakes and Reservoirs: Research and Management, Wiley Blackwell, John Wiley and sons, Australia, pp 77-88

Mishra S. P. and Jena J. G. (2013):"Characteristics of western catchment and their inflow contribution to Chilika Lagoon, Odisha (India)". International Journal of Lakes and Rivers, Volume (6), No 2, PP 119-129

Mishra S.R.(2010): “ Chilika fisheries: a place for participatory GIS" Post doctoral thesis , School of Physical, environmental and mathematical sciences, The University of New South Wales, Australian Defence Force Academy, Canberra, Australia.

Mishra, S. P. and Jena J.G. (2012): "Effects of variable inflow from Northern major rivers 
into the Chilika Lagoon, Odisha, India" International Journal of Lakes and Rivers. Volume 5, Number 2, pp. 123-132.

Mishra, S. P. and Jena J.G. (2014):" Shifting Tidal Inlets of Chilika Lagoon, Odisha, India:-A Critical Study’ (Unpublished).

Mohanty D and Adhikary S P., 2015, Study of salinity gradient of Chilika Lake before and after opening of new mouth to sea and its impact on sea weed diversity, Indian Journal of geo marine Science, Vol-44(8), pp-1176-1180

Nayak, G. K. and Rao R. C. (2006):"Aeromagnetic evidence for the arcuate shape of Mahanadi Delta". Earth's planet space. Vol 58, p. $1093-1098$.

Ojha A., Rout J., Samal. R.N, Rajesh. G, A.K Pattnaik., Daspatnaik P. (2013): Evaluation of land use and land cover dynamics of Chilika catchment", International journal of Geometrics and Geo sciences, Volume 4 No 2 pp-388-396.

Panda U. S., Mohanty P. K. (2008). Monitoring and modeling of Chilika environment using remote sensing data, In: Sengupta M, Dalwani R. (Editors), Proceedings of TAAL, 2007, The $12^{\text {th }}$ World lake conference, pp-617-638.

Pattanaik A. K. (2005):" Lake Chilika a Ramsar site from India and its ILBM challenges", Chilika Development Authority, India.

Pearson, W. (1858) . "Chilika Chart", the bathymetry map of Chilika lake, First Officer of H. M. Surveying Brig. Krishna, source Water Resources (Dept. Library Odisha).

Phillips J. D., 2017, Coastal wetlands, sea level, and the dimensions of geomorphic resilience. Geomorphology, No of Pages 12 (Article in Press).

Phillips J. D. (2017). Coastal wetlands, sea level, and the dimensions of geomorphic resilience, Elsivier, GEOMOR-05968; No of Pages 12.

Rawat, J.S., Manish Kumar and Vivekananda Biswas. (2014). Land use/cover dynamics using multi-temporal satellite imagery - A case study of Haldwani town area, district Nainital, Uttarakhand, India. International Journal of Geomatics and Geosciences, 4(3), pp.536-543.

Roy Kumuda Bhusan (1955). " Flood damages of 1955, Orissa delta". The Economic Weekly, October, 1955, PP- 1197-1199.

Sahu B. Ku, Pati P.\& Panigrahy R. C. (2014). Environmental conditions of Chilika Lake during pre and post hydrological intervention: an overview. Jour. of coastal conservation, Volume 18, pp 285-297, DOI: http://doi.org/10.1007/s11852-0140318-z.

Singh, A., Singh, S., Garga P.K. and Khanduri, K. (2013). Land Use and Land Cover Change Detection: A Comparative Approach using Post Classification Change Matrix Function Change Detection Methodology of Allahabad City. International Journal of Current Engineering and Technology, 3(1), pp.142-148.

Stevenson, G.(1922). "Control Survey of the Doabs of the costal districts of Orissa, Mr. Stvenson's report" source Water Resources Dept. Library Odisha.

Tripathy S. K. (1995). Studies on the Chemical properties of the Chilika lagoon, east 
caost of India, Ph. D. Thesis, Berhampur University, Odisha, India, PP- 1-193.

Venkatrathnam, K. (1970); "Formation of the Barrier spit and other sand ridges near Chilika Lake on the east coast of India" Marine Geology, Vol.9, Issue 2, P 101106.

Williams C. A. and Svarup Bishun (1928): "Orissa Flood committee report-1928", Irrigation Department, Government of Bihar and Orissa. ( Odisha W.R. library).

Ye, B. and Bai, Z. (2008). Simulating land use/cover changes of Nenjiang County based on C. A. Markov model. Computer and Computing Technologies in Agriculture, Vol I, pp.321-329.

Rout Jajnaseni, 2014, Monitoring lagoon coast dynamics with g-tech. Indian Journal of geomorphology, Vol 17(1), P. 9-24. 